\title{
Work-related musculoskeletal disorders and associated factors among bank workers in Addis Ababa, Ethiopia: a cross-sectional study
}

Dereje Dagne ${ }^{1}$, Solomon Mekonnen Abebe $^{2}$ and Atalay Getachew ${ }^{1 *}$

\begin{abstract}
Background: Work-related musculoskeletal disorders (WMSDs) are dramatically increased in the world due to the advancement of technology and competitiveness of markets. There were limited studies carried out regarding WMSDs among bank workers in Africa particularly in Ethiopia. Therefore, the aim of this study was to assess the magnitude of work-related musculoskeletal disorders and associated factors among bank workers in Addis Ababa, Ethiopia.

Methods: Institution-based cross-sectional study design was employed in the study. Multi-stage sampling techniques were used to select 838 bank workers from 62 banks in Addis Ababa. Self-administered standard Nordic questionnaires were used as well. Multivariable binary logistic regression analyses were employed to identify factors associated with WMSDs. Moreover adjusted odds ratio (AOR), 95\% confidence interval (Cl) and $p$ value $<0.05$ was used to show the strength of association between explanatory variables and dependent variable.

Results: Out of 838 total numbers of participants, 755 bank workers returned their questionnaires responding with a rate of $90 \%$. Of these, $77.6 \%(N=586)$ suffered WMSDs with a 95\% Cl [75-81\%]. Based on the final multivariate logistic regression analysis being female $[\mathrm{AOR}=2.98,95 \% \mathrm{Cl} 1.91-4.65]$, sitting back in a twisted position $[\mathrm{AOR}=3.59,95 \% \mathrm{Cl}$ 2.13-6.08], sitting back bent [AOR $=4.06,95 \% \mathrm{Cl} 2.48-6.66]$, work on fixed position [AOR $=1.78,95 \% \mathrm{Cl} 1.17-2.71]$, no work time break [AOR $=3.33,95 \% \mathrm{Cl} 1.44-7.71]$, type of chairs $[\mathrm{AOR}=2.62,95 \% \mathrm{Cl} 1.19-5.75]$ and job stress $[\mathrm{AOR}=$ $2.33,95 \%$ Cl 1.19-4.54] were factors significantly associated with WMSDs.

Conclusion: From the study's findings, the magnitude of work-related musculoskeletal disorders among bank workers was high. Being female, awkward posture, no work time break, fixed position, type of chairs, and job stress are the factors significantly associated with WMSDs. So bank workers should use proper types of chairs, practice proper work posture, increase healthy working conditions, and create awareness programs on how to maintain beneficial health conditions which may lead to increased leisure time.
\end{abstract}

Keywords: Bank workers, Musculoskeletal disorder, Prevalence, Work related

\footnotetext{
* Correspondence: atalayget@gmail.com

${ }^{1}$ Department of Environmental and Occupational Health and Safety, College

of Medicine and Health Science, Institute of Public Health, University of

Gondar, Gondar, Ethiopia

Full list of author information is available at the end of the article
}

C The Author(s). 2020 Open Access This article is licensed under a Creative Commons Attribution 4.0 International License, which permits use, sharing, adaptation, distribution and reproduction in any medium or format, as long as you give appropriate credit to the original author(s) and the source, provide a link to the Creative Commons licence, and indicate if changes were made. The images or other third party material in this article are included in the article's Creative Commons licence, unless indicated otherwise in a credit line to the material. If material is not included in the article's Creative Commons licence and your intended use is not permitted by statutory regulation or exceeds the permitted use, you will need to obtain permission directly from the copyright holder. To view a copy of this licence, visit http://creativecommons.org/licenses/by/4.0/. The Creative Commons Public Domain Dedication waiver (http://creativecommons.org/publicdomain/zero/1.0/) applies to the data made available in this article, unless otherwise stated in a credit line to the data. 


\section{Background}

Musculoskeletal disorder is a serious problem that every human being will face at least once throughout their lifetime. Work-related musculoskeletal disorder (WMSDs) is a soft-tissue disorder of non-traumatic origin that is caused or exacerbated by interaction with the work environment [1-4]

Every year over 2.34 million women and men die at work from an occupational injury or disease; of these, over 350,000 deaths are due to fatal accidents and almost 2 million deaths are due to fatal work-related diseases $[5,6]$. The distribution of work-related fatalities by United Nation (UN) geographical regions accounted Europe for $11.7 \%$, Oceania for $0.6 \%$, Africa for $11.8 \%$, America for $10.9 \%$, and Asia $65.0 \%$ [7]. A study conducted in Kuwait and India which focused on 12-month prevalence of WMSDs accounted $80.0 \%$ and $83.5 \%$ respectively [8, 9]. In addition, a study conducted in Nigeria and Ghana revealed that a 12-month prevalence of WMSDs among the bank workers accounted for $71.7 \%$ and $83.5 \%$ respectively $[10,11]$.

Moreover, the global compensation cost of WMSDs accounted for $40 \%$ in 2015 . This shows that WMSDs is one of the leading causes of socio-economic burden of workers due to direct and in direct costs [7]. The major factors that may influence the problem includes people sitting with their backs bent, back twisted, having no work time break, psychosocial factors, repetitive work and awkward posture [1].

The studies conducted in different countries showed that office workers including bank workers are vulnerable groups for different WMSDs [8-11]. However, there are limited studies carried out regarding WMSDs among bank workers in Africa particularly in this study setting. Hence, the focus of this study was to assess the magnitude of WMSDs and associated factors among bank workers.

\section{Methods}

\section{Study design and study population}

Institution-based cross-sectional study design was employed. This study was conducted in Addis Ababa the capital city of Ethiopia. The city is administered by a city council and organized in 10 sub-cities and 117 districts. There are about 1303 banks found in Addis Ababa in $2016 / 2017$ and an estimated number of more than 10, 000 employees who worked in those banks [12].

The source of the study's population was all bank workers engaged in bank activity in Addis Ababa, Ethiopia. The study population was all bank workers engaged in bank activity in the selected three sub-cities of Addis Ababa. For this study, bank workers who worked at least 1 year were included.

\section{Sample size and sampling procedures}

The sample size for the magnitude of WMSDs was computed based on single proportion formula by using proportion of WMSDs from a previous study conducted in Rwanda among bank workers who accounted for $45.8 \%$ [13] and a 95\% confidence interval (CI) and margin of error of $5 \%$ and $10 \%$ non-response rate. Since the sampling method was multi-stage, this study used design effect of 2 making a total sample size of 838 .

For associated factors for the occurrence of WMSDs, the sample size was computed using double population proportion formula using Epi Info software considering the different variables like sitting while back is bent, sitting while back is twisted, and work time break. But the sample sizes were low compared to the sample size for the prevalence of WMSDs. Finally, the larger sample size was taken for this study.

Study participants were selected using multi-stage sampling techniques. From 10 sub-cities, three sub-cities (Arada, Nifas silk lafto, and Kirkos) was selected randomly using lottery method. Then, the number of banks was determined in each sub-city proportionally. By using probability proportional to size (PPS) study subjects were allocated to each bank and selected by a simple random sampling technique.

\section{Data collection tools}

The standard Nordic Musculoskeletal Questionnaire (NMQ) was used to assess the magnitude of neck, shoulder, upper back, lower back, hip/thigh, knee/leg, ankle/foot, wrist/hand, and elbow musculoskeletal disorders [14]. The reliability of the Amharic version questionnaire was tested using Cronbach's alpha (Cronbach's alpha $=0.72$ ). Detailed information regarding socio-demographic factors, behavioral factors, ergonomic factors, organizational, and psychosocial factors was also included in the structured questionnaire.

\section{Data quality control}

The data collection tool was first designed in English and then translated in to the local language, Amharic and then back to English. Afterward, training was provided for four data collectors and two supervisors for 2 days, which made them familiar with the data collection procedures. Finally, a pre-test was done on $5 \%(N=42)$ of the total sample size. This was done so that those who did not participate in the main study would be addressed. Based on the pre-test analysis, unclear questions were modified. Supervisors and investigators evaluated the collected data completeness, accuracy, and clarity on a daily basis.

\section{Data processing and analysis}

The data entry and code was done by Epi Info version 7 and exported to SPSS version 20 for analysis. The 
outcome variable (WMSDs) coded as $\mathrm{No}=0$ and Yes $=$ 1. Descriptive analysis was done for both dependent and independent variables and binary logistic regression model was used to see the statistical association between different predictors and outcome variables. In this study, 18 variables with $p$ value $<0.2$ in bivariate analysis were included in multivariable logistic regression analysis model to control the effect of confounders. Model fitting was checked by using Hosmer and Lemeshow goodness of fit test, which showed $p$ value $=0.88$. Finally, adjusted odds ratio (AOR) with $95 \% \mathrm{CI}$ and $p$ value $<0.05$ was used to establish the significance of association between explanatory variables and dependent variable.

\section{Operational definitions}

- Bank workers. Employees that perform financial activities that includes supervisor, customer service, public relation, accounting clerks, loan officers, and managers

- Work-related musculoskeletal disorders. Bank workers having perceived pain, ache. or discomfort for at least 2-3 workdays in the last week or the last 12 months in any part of their bodies segments was considered [9]

- Body mass index $(B M I) .<18.5=$ underweight, 18.5$24.9=$ normal, $25.0-29.9=$ overweight, and $\geq 30.0=$ obese [15]

- Perform physical activity. Exercising or doing any kind of sport activity including walking at least 150 $\mathrm{min} /$ week [16, 17].

- Awkward posture. Bank workers perform activities with the neck bent more than 30 degrees without support, working with a bent wrist, working with the back bent without support, and squatting and kneeling for 2 or more hours continuously [18].

- Repetitive work. Perform work by repeating the same activity with less than $30 \mathrm{~s}$ or no variation every few seconds for 2 or more hours [18]

- Fixed postures. Bank workers perform activities by prolonged sitting in a limited space for 2 or more hours without changing positions [18].

- Job satisfaction. A score measured using the generic job satisfaction scale as yes (32-50) and no (10-31) [19]

- Job stress. A score measured using the workplace stress scales moderate to severe job stress as yes $(16-40)$ and no $(\leq 15)[20]$

\section{Results}

\section{Socio-demographic characteristics of the study} participants

A total of 755 bank workers returned and fully answered questionnaires making a response rate of $90 \%$. Of the total study participants, $50.7 \%(N=383)$ were females. The mean age of the study participants with standard deviation (SD) were $29.4(\mathrm{SD}=5.91)$ years. Majority of the study participants, $78.5 \%(N=593)$ religion was orthodox and more than three fourths of them had a Bachelor's degree, $75.4 \%(N=569)$. More than half, $51.2 \%(N=386)$, of the study participants were single in their marital status. About $64.6 \%(N=488)$ of the

Table 1 Socio-demographic characteristics of bank workers, Addis Ababa, Ethiopia, 2018 ( $N=755)$

\begin{tabular}{|c|c|c|}
\hline Variables/characteristics & Numbers & Percent (\%) \\
\hline \multicolumn{3}{|l|}{ Sex } \\
\hline Female & 383 & 50.7 \\
\hline Male & 372 & 49.3 \\
\hline \multicolumn{3}{|l|}{ Age } \\
\hline $20-29$ & 477 & 63.2 \\
\hline $30-39$ & 235 & 31.1 \\
\hline$\geq 40$ & 43 & 5.7 \\
\hline \multicolumn{3}{|l|}{ Religion } \\
\hline Orthodox & 593 & 78.5 \\
\hline Muslim & 54 & 7.2 \\
\hline Protestant & 88 & 11.7 \\
\hline Catholic & 20 & 2.6 \\
\hline \multicolumn{3}{|l|}{ Educational status } \\
\hline Certificate & 8 & 1.1 \\
\hline Diploma & 60 & 8.0 \\
\hline Bachelor's degree & 569 & 75.4 \\
\hline Master & 118 & 15.6 \\
\hline \multicolumn{3}{|l|}{ Marital status } \\
\hline Single & 386 & 51.2 \\
\hline Married & 367 & 48.6 \\
\hline Separated & 1 & 0.1 \\
\hline Divorced & 1 & 0.1 \\
\hline \multicolumn{3}{|l|}{ Job category } \\
\hline Accounting clerks & 34 & 4.5 \\
\hline Customer service & 488 & 64.6 \\
\hline Managers & 108 & 14.3 \\
\hline Others & 125 & 16.6 \\
\hline \multicolumn{3}{|l|}{ Salary } \\
\hline$\leq 5240$ & 196 & 26.0 \\
\hline $5241-8500$ & 212 & 28.1 \\
\hline $8501-11,200$ & 177 & 23.5 \\
\hline$>11,200$ & 169 & 22.4 \\
\hline \multicolumn{3}{|l|}{ Work experience } \\
\hline $1-5$ & 162 & 21.5 \\
\hline $6-9$ & 287 & 38.1 \\
\hline$\geq 10$ & 305 & 40.5 \\
\hline
\end{tabular}




\section{Body region affected WMSDs}

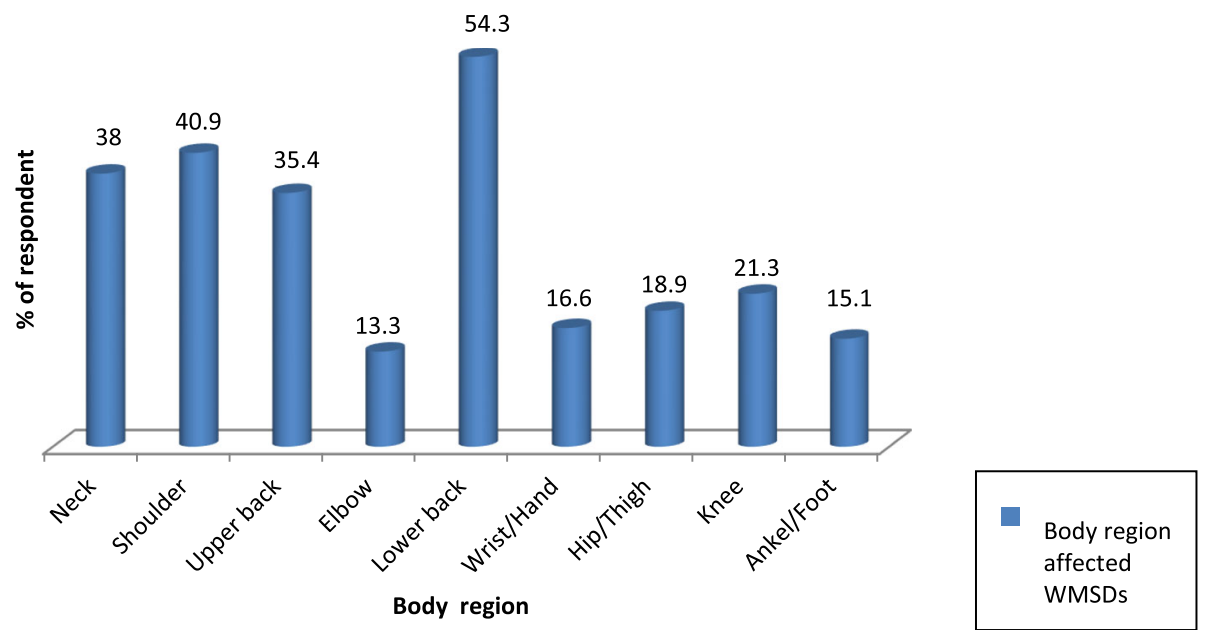

Fig. 1 The frequency of self-reported body regions affected by WMSDs among bank workers, Addis Ababa, Ethiopia, 2018

participants' job was customer service. The mean monthly income of the participants was 8794.4 (SD = 5544.0) Ethiopian Birr. About 40.5\% $(N=305)$ of the respondents worked at the bank for over 10 years (Table $1)$.

\section{Magnitude of self-reported work-related musculoskeletal disorders among bank workers}

The result of the study revealed that from the total amount of bank workers $77.6 \%$ [95\% CI 75-81\%] suffered work-related musculoskeletal disorders at least at one region of the body in the last 1 year. The four most effected body regions that the respondents reported pain or discomfort in or around were the lower back $54.3 \%$ $(N=410)$, shoulder $40.9 \%(N=309)$, neck $38.0 \%(N=$ $287)$, and upper back $35.4 \%(N=267)$, while the lowest effected body parts that the respondents reported were hip/thigh $18.9 \%(N=143)$, wrist/hand $16.6 \%(N=125)$, and ankle/foot $15.1 \%(N=114)$ (Fig. 1).

\section{Behavioral characteristics of bank workers}

The result indicated that the majority of bank workers 96.6\% $(N=729)$ were non-smokers. Regarding alcohol use $19.7 \%(N=149)$ of the respondents drank alcohol below the threshold of two times per week. The result also indicated that $45.8 \%(N=346)$ of respondents did not practice physical activities. More than half of the participants, $69.0 \%(N=521)$ had BMI in the normal range. A majority of respondents $94.3 \%(N=712)$ used their right hand to perform work-related duties, and also $96 \%(N=725)$ of bank workers did not show musculoskeletal disorder symptoms before they started bank work (Table 2).
Working environment, ergonomic characteristics, and psychosocial factor of bank workers

The study result showed that $92.8 \%(N=701)$ of bank workers performed activities at least 6 days per week. Majority, $97 \%(N=732)$, of bank workers performed

Table 2 Behavioral characteristics of bank workers in Addis Ababa, April $2018(N=755)$

\begin{tabular}{lll}
\hline Variables/characteristics & Numbers & Percent (\%) \\
\hline Smoker & 729 & 96.6 \\
No & 26 & 3.4 \\
Yes & & \\
Alcohol consumption & 47 & 6.2 \\
$\geq$ Two times per week & 149 & 19.8 \\
< Two times per week & 559 & 74.0 \\
Never & & \\
Physical activities & 346 & 45.8 \\
No & 409 & 54.2 \\
Yes & & \\
BMI & 521 & 69.0 \\
Normal & 108 & 14.3 \\
Underweight & 103 & 13.7 \\
Overweight & 23 & 3.1 \\
Obese & & 9.0 \\
Dominant hand & 712 & 94.3 \\
Right hand & 43 & 5.7 \\
Left hand & 30 & \\
History of MSDs & & \\
No & & \\
Yes & & \\
\hline
\end{tabular}


Table 3 Working environment, ergonomic characteristics, and psychosocial factors of bank workers in Addis Ababa, April 2018 $(n=755)$

\begin{tabular}{ll}
\hline Variables/characteristics & Numb \\
\hline Working days & \\
$\quad \leq 6$ days & 70 \\
7 days & 54 \\
Time spent sitting position & \\
$<2 \mathrm{~h}$ & 23 \\
$\geq 2 \mathrm{~h}$ & 73
\end{tabular}

Type of sitting posture

$\begin{array}{ll}\text { Back twisted } & 205 \\ \text { Back bent } & 308 \\ \text { Back straight } & 242 \\ \text { Utilization of computer } & \\ \text { No } & 40 \\ \text { Yes } & 715\end{array}$

Fixed position

No

Yes

Type of chair

Fixed chair

Movable chair

Arm rest chair

No
Yes
Nork break in min
Yes

Repetitive activities less than $30 \mathrm{~s}$

No

Yes

Ergonomic trainning

Yes

Customer relationship

$$
\text { Good }
$$

Poor

Boss relationship

Good

Fair

Poor

None

Colleague relationship

Good

Fair
92.8

7.2

3

97

27.2

40.8

32

5.3

94.7

47.9

52.1

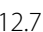

Table 3 Working environment, ergonomic characteristics, and psychosocial factors of bank workers in Addis Ababa, April 2018 $(n=755)$ (Continued)

\begin{tabular}{lll}
\hline Variables/characteristics & Number & Percent (\%) \\
\hline Poor & 12 & 1.6 \\
Job stress & 72 & 9.5 \\
No & 683 & 90.5 \\
Yes & & \\
Job satisfaction & 326 & 43.2 \\
No & 429 & 56.8 \\
Yes & & \\
\hline
\end{tabular}

their work habits by sitting more than or equal to $2 \mathrm{~h} /$ day. In addition, majority $40.8 \%(N=308)$ of bank workers were sitting with their back(s) bent. The result also indicated that $94.7 \%(N=715)$ of bank workers performed work by using a computer. More than half (52.1\%) $(N=393)$ of the workers performed activities with a fixed position. Moreover, most bank workers, 87.3\% ( $N=659)$, used movable chairs and 77.9\% ( $N=$ 588) of bank workers used arm rest chair. The finding also indicates that most bank workers, $95.1 \%(N=718)$ did not take work break in minutes. More than half, 59.7 $\%(N=451)$, did repetitive activities less than $30 \mathrm{~s}$ and only $10.7 \%(N=81)$ of the bank workers took ergonomic training. About $87.0 \%(N=657)$ of the bank workers had a good relationship with their customers. Furthermore, $71.3 \%(N=538)$ of respondents had a good relationship with their boss (Table 3).

\section{Factors associated with self-reported work-related musculoskeletal disorders}

A binary logistic regression analysis was employed to assess the effect of explanatory variables to dependent variables and 18 variables that had $p$ value less than 0.2 were included in the multivariate analysis.

Study participants who were female were 3 times more likely to develop WMSDs than male participants [AOR $=2.98,95 \%$ CI 1.91-4.65]. Respondents sitting with their back twisted were 3.6 times more likely to develop WMSDs $[\mathrm{AOR}=3.59,95 \%$ CI 2.13-6.08], and respondents sitting with their back bent were 4 times more likely to develop WMSDs $[\mathrm{AOR}=4.06,95 \%$ CI $2.48-$ 6.66] when compared to sitting back straight. Moreover, respondents who worked with fixed position were 1.8 times more likely to develop WMSDs $[\mathrm{AOR}=1.78,95 \%$ CI, 1.17-2.71] than those who worked without fixed position. Participants sitting in fixed chairs were 2.6 times more likely to develop WMSDs $[\mathrm{AOR}=2.62,95 \%$ CI 1.19-5.75] than those who sat in movable chairs. And respondents who had no work time breaks were 3 times more likely to develop WMSDs $[\mathrm{AOR}=3.33,95 \%$ 
Table 4 Multi variable analysis of factors associated with workrelated musculoskeletal disorders among bank workers, Addis Ababa, Ethiopia, $2018(N=755)$

\begin{tabular}{llll}
\hline Variable & Frequency & COR $(95 \% \mathrm{Cl})$ & AOR $(95 \% \mathrm{Cl})$ \\
\cline { 2 - 3 } & No Yes & \\
\hline
\end{tabular}

\begin{tabular}{lllll}
\hline $\begin{array}{l}\text { Sex } \\
\text { Female }\end{array}$ & 51 & 332 & $3.02[2.09-4.36]$ & $2.98[1.91-4.65]^{* *}$ \\
$\quad$ Male & 118 & 254 & 1.00 & 1.00 \\
Age & & & & \\
$20-29$ & 115 & 362 & 1.00 & 1.00 \\
$30-39$ & 49 & 186 & $1.21[0.83-1.76]$ & $1.09[0.66-1.83]$ \\
$\geq 40$ & 5 & 38 & $2.414[0.92-6.27]$ & $3.05[0.86-10.73]$ \\
Educational status & & & & \\
Certificate & 4 & 4 & $0.17[0.04-0.74]$ & $0.260[0.03-1.821]$ \\
Diploma & 21 & 39 & $0.31[0.14-0.65]$ & $0.949[0.30-2.98]$ \\
Bachelor's degree & 127 & 442 & $0.58[0.33-1.01]$ & $0.666[0.33-1.32]$ \\
Master & 17 & 101 & 1.00 & 1.00
\end{tabular}

Job catagory

$\begin{array}{lllll}\text { Accounting clerks } & 14 & 20 & 0.32[0.14-0.73] & 0.23[0.06-0.79] \\ \text { Customer service } & 115 & 373 & 0.73[0.44-1.20] & 0.85[0.46-1.57] \\ \text { Managers } & 17 & 91 & 1.20[0.60-2.40] & 1.56[0.65-3.73] \\ \text { Others } & 23 & 102 & 1.00 & 1.00\end{array}$

Salary

$\leq 5240$

$5241-8500$

$8501-11200$

$>11200$

Smoking behavior

$\begin{array}{lllll}\text { No } & 166 & 563 & 1.00 & 1.00 \\ \text { Yes } & 3 & 23 & 2.26[0.67-7.62] & 2.57[0.47-14.08]\end{array}$

BMI

$\begin{array}{lllll}\text { Normal } & 117 & 404 & 1.00 & 1.00 \\ \text { Underweight } & 20 & 83 & 1.27[0.75-2.15] & 1.01[0.54-1.89] \\ \text { Overweight } & 30 & 73 & 0.70[0.44-1.13] & 0.82[0.46-1.48] \\ \text { Obese } & 2 & 21 & 3.04[0.70-13.15] & 3.10[0.60-15.87]\end{array}$

History of MSDs

$\begin{array}{lllll}\text { No } & 167 & 558 & 1.00 & 1.00 \\ \text { Yes } & 2 & 28 & 4.19[0.98-17.77] & 3.46[0.68-17.48]\end{array}$

Type of sitting position

$\begin{array}{lllll}\text { Back twisted } & 28 & 177 & 4.76[2.96-7.65] & 3.59[2.13-6.08]^{* *} \\ \text { Back bent } & 37 & 271 & 5.52[3.60-8.46] & 4.06[2.48-6.66]^{* *} \\ \text { Back straight } & 104 & 138 & 1.00 & 1.00\end{array}$

Utilization of computer

$\begin{array}{lllll}\text { No } & 15 & 25 & 1.00 & 1.00 \\ \text { Yes } & 154 & 561 & 2.18[1.12-4.24] & 2.38[0.94-5.99]\end{array}$

Work break in $\min$

No

$148570 \quad 5.05[2.57-9.93] \quad 3.33[1.44-7.71]^{* *}$
Table 4 Multi variable analysis of factors associated with workrelated musculoskeletal disorders among bank workers, Addis Ababa, Ethiopia, 2018 ( $N=755)$ (Continued)

\begin{tabular}{|c|c|c|c|c|}
\hline \multirow[t]{2}{*}{ Variable } & \multicolumn{2}{|c|}{ Frequency } & \multirow[t]{2}{*}{ COR (95\% Cl) } & \multirow[t]{2}{*}{ AOR $(95 \% \mathrm{Cl})$} \\
\hline & No & Yes & & \\
\hline Yes & 21 & 16 & 1.00 & 1.00 \\
\hline \multicolumn{5}{|c|}{ Repetitive motion } \\
\hline No & 83 & 221 & 1.00 & 1.00 \\
\hline Yes & 86 & 365 & 1.59 [1.12-2.25] & $1.15[0.74-1.78]$ \\
\hline \multicolumn{5}{|c|}{ Fixed position } \\
\hline No & 107 & 255 & 1.00 & 1.00 \\
\hline Yes & 62 & 331 & $2.24[1.57-3.18]$ & $1.78[1.17-2.71]^{* *}$ \\
\hline \multicolumn{5}{|c|}{ Boss relation } \\
\hline Good & 138 & 400 & 1.00 & 1.00 \\
\hline Fair & 21 & 144 & $2.36[1.44-3.89]$ & $1.97[1.00-3.56]$ \\
\hline Poor & 3 & 21 & $2.41[0.71-8.22]$ & $1.18[0.31-4.45]$ \\
\hline None & 7 & 21 & $1.03[0.43-2.49]$ & $1.90[0.64-5.64]$ \\
\hline
\end{tabular}

Customer relation

$\begin{array}{lllll}\text { Good } & 159 & 498 & 1.00 & 1.00 \\ \text { Poor } & 10 & 88 & 2.81[1.42-5.53] & 1.91[0.86-4.25]\end{array}$

Type of chairs

$\begin{array}{lllll}\text { Fixed } & 11 & 85 & 2.44[1.26-4.68] & 2.6[1.19-5.75]^{* *} \\ \text { Movable } & 158 & 501 & 1.00 & 1.00\end{array}$

Job satisfaction

$\begin{array}{lllll}\text { No } & 60 & 266 & 1.51[1.06-2.15] & 0.98[0.62-1.53] \\ \text { Yes } & 109 & 320 & 1.00 & 1.00\end{array}$

Job stress

$\begin{array}{lllll}\text { No } & 30 & 42 & 1.00 & 1.00\end{array}$

Yes $\quad 139 \quad 544 \quad 2.79[1.69-4.63] \quad 2.33[1.19-4.54]^{*}$

Others public relations, loan officers, supervisors; $A O R$ adjusted odd ratio; $\mathrm{Cl}$ confidence interval

*Statistically significant at $p$ value $<0.05$

**Statistically significant at $p$ value $<0.001$

CI 1.44-7.71] than those who had work time breaks. Furthermore, respondents who had job stress were 2 times more likely to develop WMSDs $[\mathrm{AOR}=2.33$, 95\% CI 1.19-4.54] than workers who had no job stress (Table 4).

\section{Discussion}

Findings of this study reveal that $77.6 \%$ [95\% CI $75-$ $81 \%]$ of bank workers suffered work-related musculoskeletal disorders. This study was consistent with a study conducted among bank workers in Kuwait (80\%) [9]. But higher compared to the studies done in Nigeria $71.6 \%$ [10], India 37\% [21], and Thailand 63\% [22].

By contrast, the current study had lower magnitude as compared to the study conducted in India/Punjab 83.5\% [8] and Ghana 83.5\% [11]. The difference might be due to difference in sociocultural factors, job stress [21], 
assessment tools, workload, ergonomic design of work station, and sedentary activity of participants [11].

The result of this study revaled that female respondents were 3 times more likely to develop WMSDs than male participants. This was similar to a study conducted in Kuwait [9], India [21], Ghana [11], Sri Lanka [23], and Nigeria [10]. However, this study was inconsistent to a study conducted among bank workers in India [8] and Bangladesh [24]. This disparity might be due to work load and sociocultural factor [21, 25].

In this study, it has been observed that the type of sitting position was an important predictor of WMSDs among bank workers. Respondents sitting with their back twisted were 3.6 times more likely to develop WMSDs than sitting with their back straight. This finding was consistent with studies done in Rwanda [13] and Dutch [26]. On the other hand, respondents sitting with their back bent were 4 times more likely to develop WMSDs than sitting with a straight aligned back. This finding was in agreement with studies done in Rwanda [13], Sri Lanka [23], Dutch [26], and China [27]. This is due to the fact that poor posture can bring stiffness and compression over all muscle and skeletal areas causing aching and discomfort of body regions [28, 29].

In addition to this, respondents who worked with a fixed position were 1.8 times more likely to develop WMSDs than those workers who worked without fixed position. This was consistent with different studies done on WMSDs of the neck, lower back, and shoulder regions of the body [10, 23, 30-33]. This might because when workers work in a fixed position, the muscle has no opportunity to relax and it restricts the flow of blood [34]

Respondents who had no work time breaks were 3 times more likely to develop WMSDs than those who had work time break. The findings of this study were consistant with the study conducted in Ethiopia [35], Rwanda [13], and China [27]. Most of the participants of this study used movable chairs to perform their work time duties, although sitting in fixed chairs had 2.6 times more likely to develop WMSDs than sitting on movable ones.

Furthermore, respondents who had job stress were 2 times more likely to develop WMSDs than workers who had no job stress. This finding was consistent with studies done among bank workers in Kuwait [9]. This could be due to the fact that high stress may increase muscle tension and decrease micro pauses in muscle activity [11].

Though the study did its best to indicate the magnitude of WMSDs among bank workers, it is not free from limitations. The cross-sectional design might have prevented the work from showing temporal relationships. In addition, since WMSDs has not been verified by clinical diagnosis in the last 12 months, our result is based on self-reporting. Thus, it is possible that participants failed to remember correctly and ultimately end up in a recall bias. In addition, this study did not assess the amount of personal computer and smart phone usage in private and business.

\section{Conclusion}

The finding of this study has shown that bank workers highly suffered from work-related musculoskeletal disorders at least in one region of the body in the previous 12 months. Of these, high prevalent body regions were the lower back followed by the shoulder, neck, and upper back. The multivariate analysis indicated that the significant predictors for the occurrence of WMSDs among bank workers were being female, awkward posture, static position, no work time break, type of chairs and job stress. In order to reduce the problem, bank workers should employ proper types of chairs, practice proper work posture, healthy working conditions, and create awareness programs on how to maintain healthy conditioning and to have enough leisure time.

\section{Supplementary information}

Supplementary information accompanies this paper at https://doi.org/10. 1186/s12199-020-00866-5.

Additional file 1: Table 1. Socio-demographic characteristics of bank workers, Addis Ababa, Ethiopia, $2018(\mathrm{~N}=42)$. Table 2. Behavioral characteristics of bank workers in Addis Ababa, April 2018 ( $n=42)$.

\section{Abbreviations}

AOR: Adjusted odd ratio; Cl: Confidence interval; BMI: Body mass index; ILO: International Labor Organization; NMQ: Nordic Musculoskeletal Questionnaire; OSHA: Occupational Safety and Health Administration; SD: Standard deviation; SPSS: Statistical Package for Social Science; WMSDs: Work-related musculoskeletal disorders; WHO: World Health Organization

\section{Acknowledgements}

We would like to thank the University of Gondar's College of Medicine and Health Sciences for delivering an ethical clearance for this study. We would also like to extend our heartfelt appreciation to the banks found in Addis

Ababa for giving us permission to conduct this study. We greatly

acknowledge the study participants for their active participation.

\section{Authors' contributions}

DD contributed to the study design, data collection and analysis, interpretations of the results, manuscript write-up, and review. SM contributed in study design, data analysis, interpretation of the result, and manuscript review. AG contributed to the study design, data analysis, interpretation of the result, and manuscript write-up and review. All authors read and approved the final manuscript.

Funding

There is no source of funding.

\section{Availability of data and materials}

All data generated or analyzed during this study are included in this article. The data that support the findings of this study are also available from the corresponding authors upon reasonable request.

\section{Ethics approval and consent to participate}

Ethical clearance was obtained from the institutional Ethical committee of the University of Gondar (reference number /IPH/260/2017). Then, official letters were sent to the head office of banks found in Addis Ababa city 
administration as well as different branches of banks found in the city. For each participant, the purpose and importance of the study were explained and informed by written information sheet. The study maintained confidentially at all levels. Participant's involvement in the study was on a voluntary basis; participants who were unwilling to participate in the study were respected. Therefore, the study agreed with the Helsinki Declaration of 1964 and its related amendments in this regard.

\section{Consent for publication}

Not applicable.

\section{Competing interests}

The authors declare that they have no competing interests.

\section{Author details}

'Department of Environmental and Occupational Health and Safety, College of Medicine and Health Science, Institute of Public Health, University of Gondar, Gondar, Ethiopia. ${ }^{2}$ Department of Human Nutrition, College of Medicine and Health Science, Institute of Public Health, University of Gondar, Gondar, Ethiopia.

Received: 6 December 2019 Accepted: 23 June 2020

Published online: 27 July 2020

\section{References}

1. Darvishi E, Maleki A, Giahi O, Akbarzadeh A. Subjective mental workload and its correlation with musculoskeletal disorders in bank staff. Journal of Manipulative and Physiological Therapeutics. 2016;39(6):420-6.

2. Luttmann A, Jäger M, Griefahn B, Caffier G, Liebers F, Steinberg U. Preventing musculoskeletal disorders in the workplace. Geneva: WHO; 2003.

3. OSHA. musculo skeletal disorders. Ergonomics: the study of work: U.S. Department of Labor Occupational Safety and Health Administration; 2000. p. $2-5$.

4. Nunes IL, Bush PM. Work-related musculoskeletal disorders assessment and prevention. Ergonomics-A Systems Approach: InTech. 2012.

5. ILO. The prevention Of occupational diseases Geneva: International Labour office; 2013.

6. ILO. Global trends on occupational accidents and diseases. WORLD DAY FOR SAFETY AND HEALTH AT WORK. 2015:1-2.

7. Hämäläinen P, Takala J, Kiat TB. Global estimates of occupational accidents and work-related illnesses 2017. Workplace Safety and Health Institute, 2017 9789811148446

8. Moom RK, Sing LP, Moom N. Prevalence of musculoskeletal disorder among computer bank office employees in Punjab (India): a case study. Procedia Manufacturing. 2015;3:6624-31.

9. Akrouf Q, Crawford J, Al Shatti A, Kamel M. Musculoskeletal disorders among bank office workers in Kuwait; 2010.

10. Maduagwu SM, Maijindadi RD, Duniya Kl, Oyeyemi AA, Saidu IA, Aremu BJ. Prevalence and patterns of work-related musculoskeletal disorders among bankers in Maiduguri, Northeast Nigeria. Occupational Medicine \& Health Affairs. 2014:1-6.

11. Abledu J, Abledu G. Multiple logistic regression analysis of predictors of musculoskeletal disorder and disability among bank workers in Kumasi. Ghana J Ergon. 2012;2:111-5.

12. Ethiopia NBo. Quarterly Bulletin. Addis Ababa: 2016/17 3.

13. Kanyenyeri $L$, Asiimwe B, Mochama M, Nyiligira J, Habtu M. Prevalence of back pain and associated factors among bank staff in selected banks in Kigali, Rwanda: a cross sectional study. Health Science Journal. 2017;11(3).

14. Kuorinka I, Jonsson B, Kilbom A, Vinterberg H, Biering-Sørensen F, Andersson G, et al. Standardised Nordic questionnaires for the analysis of musculoskeletal symptoms. Applied ergonomics. 1987;18(3):233-7.

15. WHO. Obesity: preventing and managing the global epidemic: World Health Organization; 2000.

16. Rolander B, Bellner A-L. Experience of musculo-skeletal disorders, intensity of pain, and general conditions in work--the case of employees in non-private dental clinics in a county in southern Sweden. Work. 2001;17(1):65-73.

17. WHO. Global recommendations on physical activity for health. Geneva: World Health Organization; 2010. 2016.

18. Kunda R, Frantz J, Karachi F. Prevalence and ergonomic risk factors of workrelated musculoskeletal injuries amongst underground mine workers in Zambia. Journal of occupational health. 2013;55(3):211-7.
19. Macdonald S, Maclntyre P. The generic job satisfaction scale: Scale development and its correlates. Employee Assistance Quarterly. 1997;13(2): $1-16$.

20. Stress; TAlo. Attitudes in the American workplace VII. 2011.

21. Sulaiman SK, Kamalanathan P, Ibrahim AA, Nuhu JM. Musculoskeletal disorders and associated disabilities among bank workers. International Journal of Research in Medical Sciences. 2017;3(5):1153-8.

22. Janwantanakul $P$, Pensri $P$, Jiamjarasrangsri $V$, Sinsongsook $T$. Prevalence of self-reported musculoskeletal symptoms among office workers. Occupational medicine. 2008;58(6):436-8.

23. Ranasinghe P, Perera YS, Lamabadusuriya DA, Kulatunga S, Jayawardana N, Rajapakse S, et al. Work related complaints of neck, shoulder and arm among computer office workers: a cross-sectional evaluation of prevalence and risk factors in a developing country. Environmental Health. 2011;10(1):70.

24. Towhid EA. Prevalance of low back pain among the bank workers at some selected banks in Savar: Department of Physiotherapy. CRP: Bangladesh Health Professions Institute; 2012.

25. Jensen C, Ryholt C, Burr H, Villadsen E, Christensen H. Work-related psychosocial, physical and individual factors associated with musculoskeletal symptoms in computer users. Work \& Stress. 2002;16(2):107-20.

26. Eltayeb S, Staal JB, Hassan A, De Bie RA. Work related risk factors for neck, shoulder and arms complaints: a cohort study among Dutch computer office workers. Journal of occupational rehabilitation. 2009;19(4):315.

27. Wu S, He L, Li J, Wang J, Wang S. Visual display terminal use increases the prevalence and risk of work-related musculoskeletal disorders among Chinese office workers: a cross-sectional study. Journal of occupational health. 2012;54(1):34-43.

28. OSHA. Musculo skeletal disorders. Ergonomics: The Study of Work: U.S. Department of Labor Occupational Safety and Health Administration; April 20, 2000. p. 2-5.

29. Simoneau S, St-Vincent M, Chicoine D. Work-related musculoskeletal disorders (WMSDs)-a better understanding for more effective prevention. Association paritari por la santé at la sécurité du travail Institute de recherché Robert-Sauvé en santé et en sécurité du travail du Quebéc. 2003.

30. Winkel J. Westgaard RH. A model for solving work related musculoskeletal problems in a profitable way: Elsevier; 1996.

31. Devereux J, Vlachonikolis I, Buckle P. Epidemiological study to investigate potential interaction between physical and psychosocial factors at work that may increase the risk of symptoms of musculoskeletal disorder of the neck and upper limb. Occupational and environmental medicine. 2002;59(4):26977.

32. Alavi SS, Makarem J, Abbasi M, Rahimi A, Mehrdad R. Association between upper extremity musculoskeletal disorders and mental health status in office workers. Work. 2016;55(1):3-11.

33. Sheahan PJ, Diesbourg TL, Fischer SL. The effect of rest break schedule on acute low back pain development in pain and non-pain developers during seated work. Applied ergonomics. 2016;53:64-70.

34. WHO. Preventing musculoskeletal disorders in the work place. Protecting workers health Geneva: World Health Organization; 2003.

35. Wami SD, Dessie A, Chercos DH. The impact of work-related risk factors on the development of neck and upper limb pain among low wage hotel housekeepers in Gondar town, Northwest Ethiopia: institution-based crosssectional study. Environmental health and preventive medicine. 2019;24(1):27.

\section{Publisher's Note}

Springer Nature remains neutral with regard to jurisdictional claims in published maps and institutional affiliations.

\section{Ready to submit your research? Choose BMC and benefit from:}

- fast, convenient online submission

- thorough peer review by experienced researchers in your field

- rapid publication on acceptance

- support for research data, including large and complex data types

- gold Open Access which fosters wider collaboration and increased citations

- maximum visibility for your research: over $100 \mathrm{M}$ website views per year

At BMC, research is always in progress.

Learn more biomedcentral.com/submissions 